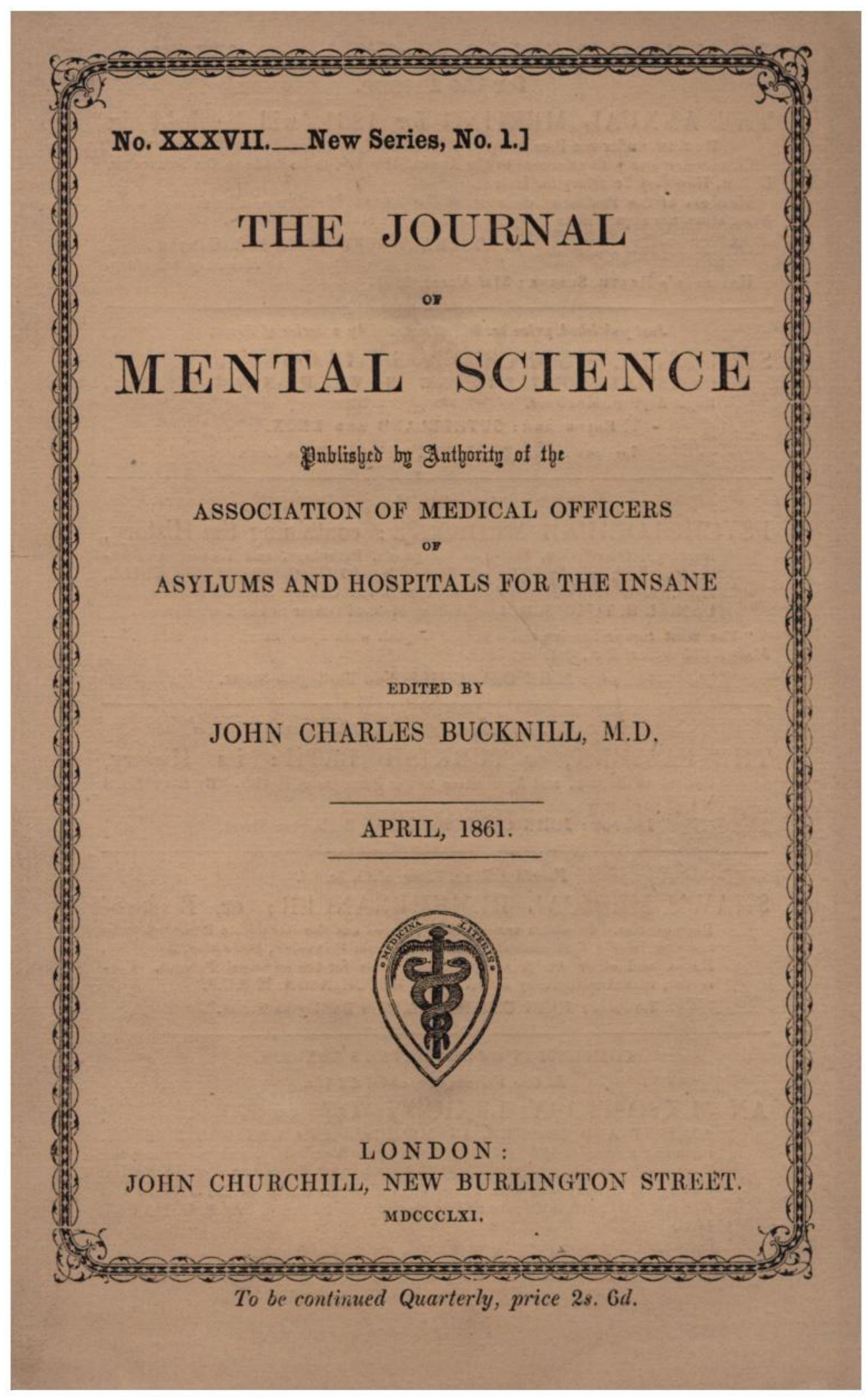




\section{Association of Medical Officers of Asylums and Hospitals for the Insane.}

THE ANNUAL MEETING for 1861, will be held in Dublis, under the Presidency of Dr. LALOR, in JuLy.

Communications with reference to the Annual Meeting, to be made to Dr. STrwart, Belfast, Honorary Secretary for Ireland.

Members of the Profession desirous at the Annual Meeting of admission into the Association, are requested to apply by Letter to the Honorary Secretary.

C. LOCKHart robertson, M.B. Cantab.,

HaYward's Hzath, Sussex; 31st March, 1861.

Honorary Secretary.

Just published, price 18. 6d., illustrated by a Series of Plans,

SUGGESTIONS CONCERNING THE CONSTRUCTION OP ASYLUMS FOR THE INSANE. By WM. DEAN FAIRLESS, M.D., Royal Asylum, Montrose.

BDiNBURG : SUTHERLAND AND KNOX.

London : H. J. TRESIDDER, 17, Ave-Maria Lane.

$8 \mathrm{vo}$, cloth, $15 s$.

PSYCHOLOGICAL MEDICINE : containing the History, Nosology, Description, Statistics, Diagnosis, Pathology, and Treatment of Insanity. With an Appendix of Cases. By JOHN CHARLES BUCKNILL, M.D., Medical Superintendent of the Devon County Lunatic Asylum, and DANIEL H. TUKE, M.D., late Visiting Medical Officer to the York Retreat.

"The most comprehensive and practical English work upon insanity now extant."Medico-Chirurgical Rev., October, 1860.

LONDON : JOHN CHURCHILL, New Burlington Street.

Just published, fcap. 8vo, $2 s$.

THE EASTERN, or TURKISH BATH : its History, Revival in Britain, and Application to the Purposes of Health. By ERASMUUS WILSON, F.R.S.

LoNDow : JOHN CHURCHILL, New Burlington Street.

Fourth Edition, $32 \mathrm{mo}$, cloth, 2s. $6 d$.

SHAW'S MEDICAL REMEMBRANCER; or, Book of Emergencies. In which are concisely pointed out the immediate Remedies to be adopted in the first moments of Danger from Poisoning, Drowning, Apoplexy, Burns, and other Accidents; with the Tests for the principal Poisons. Corrected, with Additions, by JONATHAN HUTCHINSON, M.R.C.S.

LoNdoN : JOHN CHURCHILL, New Burlington Street.

COMPIETION OF DR. MAYNE'S LBXICON.

In One Volume, 8vo, cloth, £2 10 s.

AN EXPOSITORY LEXICON OF 50,000 TERMS, ANCIENT AND MODERN, IN MEDICAL AND GENERAL SCIENCE, including a complete Medical and Medico-legal Vocabulary, and presenting the Correct Pronunciation, Derivation, Definition, and Explanation of the Names, Analogues, Synonymes, and Phrases (in English, Latin, Greek, French, and German) employed in Science and connected with Medicine. By R. G. MAYNE, M.D.

JOHN CHURCHILL, New Burlington Street. 


\section{CONTENTS.}

Second Croonian Lecture, by Dr. SutherLavd $\ldots \ldots \ldots \ldots .1$

History of Psychology, by Mr. J. C. Browne ............. 19

Gheel and Cottage Asylums, by Dr. Srbbaxd ............ 31

Endemic Degeneration, by W. A. F. Browse, Esq., Commissioner in Lunacy for Scotland .................... 61

Animal Magnetism. From the French of M. AurREd DE MAURX ........................................... 76

German Psychology, condensed from ' Zeitschrift für Psychiatrie,' by Dr. ArLIdge $\ldots \ldots \ldots \ldots \ldots \ldots \ldots \ldots \ldots . . \ldots 6$

Suicide and Life Insurance, by Dr. DAvEr $\ldots \ldots \ldots \ldots \ldots . . . . . .107$

Case of Homicidal Mania, with Remarks, by Dr. Robertsow ... 120

Licences and Certificates of Insanity, by Dr. Coworlr ..... 127

Quarterly Psychological Review, and Notes on Books, by the Editor.................................................. 136 